\title{
Cell death in three marine diatom species in response to different irradiance levels, silicate, or iron concentrations
}

\author{
Klaas R. Timmermans*, Marcel J. W. Veldhuis, Corina P. D. Brussaard \\ Royal Netherlands Institute for Sea Research, Department of Biological Oceanography, PO Box 59, 1790 AB Den Burg, \\ Texel, The Netherlands
}

\begin{abstract}
The effects of light, silicate, or iron limitation on cell death rates and the accompanying effects on growth rates and photosynthetic efficiencies were investigated for 3 species of marine diatoms, Chaetoceros brevis, Chaetoceros calcitrans and Thalassiosira antarctica. Cell death rates were based on changes in time of the percentage dead cells using the SYTOX Green membrane permeability assay. The death rates increased with decreasing irradiance levels and silicate concentrations for T. antarctica. In contrast, the cell death rates were hardly affected by low irradiances or silicate for $C$. brevis and C. calcitrans. Iron limitation experiments did not affect algal death rates significantly in the species tested. Growth rates under limiting conditions decreased from 0.6-0.4 to $0.2-0.1 \mathrm{~d}^{-1}$, and only under low light conditions did growth halt completely. Photosynthetic efficiencies did not always co-vary with cell death rates and were shown to be a sensitive indicator of light and iron limitation, but not of silicate limitation. This is the first detailed study providing data on diatom cell death under different growth-limiting conditions. The differential response in cell death rates indicates irradiance as a determining factor in diatom species succession and distribution.
\end{abstract}

KEY WORDS: Cell death $\cdot$ Growth $\cdot$ Marine diatoms $\cdot$ Iron $\cdot$ Irradiance $\cdot$ Silicate $\cdot$ SYTOX Green

\section{INTRODUCTION}

So far, most efforts to understand the diatoms' success have been focussed on growth-related processes. The effects of light and variable irradiance levels on marine diatom growth have been the subject of many studies (Geider et al. 1986, Berges \& Falkowski 1998, Timmermans et al. 2001a, Boyd et al. 2002, MacIntyre et al. 2002). In a similar manner, the effects of silicate on diatom growth are also well documented (see review by Martin-Jézéquel et al. 2000, and references therein). More recently, the effects of iron as a growthcontrolling factor on diatoms were studied (Sunda \& Huntsman 1995, Timmermans et al. 2001b). However, it is clear that for a complete understanding of diatom biomass and species distribution, the investigation of growth in relation to environmental conditions and changes is not sufficient. Loss parameters have to be taken into account as well. Traditionally, grazing and/or sedimentation have been considered the major loss factors for phytoplankton cells in oceans. It is evident by now that we cannot balance the growth and losses of phytoplankton in many ecosystems based on these 2 loss terms only (Walsh 1983, Van Boekel et al. 1992, Brussaard et al. 1995, Bidle \& Falkowski 2004). Increasing evidence points to cell death as a third major algal loss factor (Kirchman 1999, Agustí \& Duarte 2000, Brussaard 2004, Franklin et al. 2006). Due to the development of sensitive fluorescent stains in combination with single cell analysis, an awareness of the importance of viruses as mortality agents, and the discovery of programmed cell death in algae, the research on algal cell death has gone through a remarkable evolution (Brussaard et al. 1996, Berges \& Falkowski 1998, Agustí \& Sánchez 2002, Bidle \& Falkowski 2004, Franklin \& Berges 2004, Franklin et al. 2006).

Still, the number of laboratory studies on physiological cell death in diatoms is very limited. There are the 
studies by Lee \& Rhee $(1997,1999)$ under N or P limitation and light limitation, respectively, but these were performed on freshwater cyanobacteria. The marine diatom Ditylum brightwellii was also studied under N and P limitation, showing that nutrient-stress-induced cell lysis was a significant loss factor (Brussaard et al. 1997). Peters \& Thomas (1996) and Peters (1996) have studied diatom cell death responses in relation to prolonged darkness. The diatom Thalassiosira weissflogii hardly showed any cell death after $6 \mathrm{~d}$ of light deprivation, whereas significant death was found in response to nitrogen stress; in contrast, the chlorophyte Dunalliela tertectiola showed massive cell death in connection with light deprivation (Berges \& Falkowski 1998).

The specific objectives of the present study were to quantify cell death rates, together with growth rates and photosynthetic efficiencies, of diatoms in response to light, silicate, or iron limitation. The fluorochrome SYTOX Green was used to discriminate between live and dead cells. Two Antarctic diatoms (Chaetoceros brevis, Thalassiosira antarctica) and 1 temperate diatom (Chaetoceros calcitrans) were tested. We relate variations to the possible differences in autoecology between the different diatom species.

\section{MATERIALS AND METHODS}

Algal cultures and general culture conditions. Unialgal, xenic cultures of Chaetoceros brevis, Thalassiosira antarctica and Chaetoceros calcitrans originating from the Royal NIOZ culture collection were used. These diatoms are typically small species with diameters of 3 to $6 \mu \mathrm{m}$ and cell volumes in the range of 30 to $60 \mathrm{\mu m}^{3}$. The diatoms were incubated in $125 \mathrm{ml}$ polycarbonate bottles at $4^{\circ} \mathrm{C}\left(\mathrm{C}\right.$. brevis, $T$. antarctica) or $15^{\circ} \mathrm{C}$ (C. calcitrans). The diatoms were grown under semicontinuous conditions at constant growth rates. When cell abundances became too high $\left(>100000\right.$ cells ml$\left.^{-1}\right)$, the diatoms were diluted with fresh growth medium to approximately 100 cells $\mathrm{ml}^{-1}$, as to prevent nutrient depletion and effects of self-shading. The cultures growing at the highest rates (i.e. grown at the highest irradiance levels, silicate, or iron concentrations) determined the time of dilution for all cultures. These dilution steps were repeated at least twice, in order to acclimate the diatoms to the experimental conditions of nutrient or low light stress. The growth media consisted of either natural, filtered Southern Ocean seawater for the irradiance and iron experiments, or natural, filtered, nutrient-poor surface water from the Canary Basin for the silicate experiments. All filtrations were done using Sartobran $0.2 \mu \mathrm{m}$ pore size filters. The Southern Ocean water had background concentrations of $26.1 \mu \mathrm{M}$ nitrate, $24.5 \mu \mathrm{M}$ reactive silicate, $1.82 \mu \mathrm{M}$ orthophos- phate and $0.3 \mathrm{nM}$ dissolved iron. The Canary Basin water had background concentrations of nitrate, reactive silicate and orthophosphate concentrations of 0.8 , 0.7 and $<0.05 \mu \mathrm{M}$, respectively. The culture bottles were cleaned with $1 \mathrm{M} \mathrm{HCl}$ prior to use, followed by rinses with Milli-Q water (3 times, of which the last was with boiling Milli-Q). Finally, the bottles were dried in a laminar flow bench and stored sealed till used. This treatment rendered trace-metal-clean and sterile bottles. All handling of the incubations was done in a laminar flow bench to prevent contamination by microorganisms and/or trace metals. A 16:8 h light:dark photoregime, with cool white fluorescence tubes (Phillips TLD 36W/54) as a light source, was maintained throughout all experiments. Light intensities of $100 \mu \mathrm{mol}$ photons $\mathrm{m}^{-2} \mathrm{~s}^{-1}$ were maintained (except for the irradiance experiments, see below).

Irradiance experiments. Nitrate, reactive silicate and orthophosphate were added to the filtered seawater to final concentrations of 80,80 and $5 \mu \mathrm{M}$, respectively. With respect to micro-nutrients, only $10 \mathrm{nM} F$ and $10 \mathrm{nM}$ Mn (final concentrations) were added. Effects of nutrient depletion on cell death can be excluded in our study, since nutrients were still present at sufficiently high concentrations at the time of the experiments (data not shown, $>30 \mu \mathrm{M} \mathrm{N}$ and $\mathrm{Si}_{1}>3 \mu \mathrm{M} \mathrm{P}$ ) and low biomass cultures were maintained throughout. The diatoms were incubated under 7 (Chaetoceros brevis, Thalassiosira antarctica) or 6 (Chaetoceros calcitrans) different irradiance levels from light-replete to lightlimited intensities (Table 1). A gradient of irradiances was created by fixing neutral screens over the incubation bottles, in combination with placing the incubation bottles at different distances to the light source. The neutral screens ensured an unaltered photosynthetically active radiation (PAR) light spectrum inside the incubation bottles. The irradiance level inside each individual incubation bottle was measured with a QSL100 irradiance meter (Biospherical Instruments). The intensity of the cool white fluorescence tubes was checked monthly in a calibration bottle, to determine the change in light intensity over time. Less than $10 \%$ change of the initial intensity was measured.

Silicate experiments. As the background silicate concentration $(0.7 \mu \mathrm{M})$ in the growth medium was not low enough to induce silicate limitation in any of the 3 species tested, diatoms were used to further deplete silicate from seawater. After the diatoms ceased growing in these cultures, the water was gently filtered using $0.2 \mu \mathrm{m}$ pore size polycarbonate filters, resulting in background silicate concentrations of $0.18 \mu \mathrm{M}$. This preconditioned water was used as a basis for the preparation of new growth medium. Macro- and micronutrients (including iron), standard for $f / 2$ medium, were routinely added, except silicate, which was 
Table 1. Average $( \pm \mathrm{SE})$ photosynthetic efficiencies $\left(F_{\mathrm{v}} / F_{\mathrm{m}}, \mathrm{n}=5\right)$ in cultures of Chaetoceros brevis, Thalassiosira antarctica and Chaetoceros calcitrans in response to different irradiances $(I)$, silicate, or iron $\left(\mathrm{Fe}^{\prime}\right)$ concentrations. n.d.: not determined; a.u.: arbitrary units

\begin{tabular}{|c|c|c|c|c|c|}
\hline $\begin{array}{l}I \\
(\mu \mathrm{mol} \text { photons } \\
\left.\mathrm{m}^{-2} \mathrm{~s}^{-1}\right)\end{array}$ & $\begin{array}{l}F_{\mathrm{v}} / F_{\mathrm{m}} \\
\text { (a.u.) }\end{array}$ & $\begin{array}{c}\text { Silicate } \\
(\mu \mathrm{M})\end{array}$ & $\begin{array}{l}F_{\mathrm{v}} / F_{\mathrm{m}} \\
\text { (a.u.) }\end{array}$ & $\begin{array}{l}\mathrm{Fe}^{\prime} \\
(\mathrm{M})\end{array}$ & $\begin{array}{l}F_{\mathrm{v}} / F_{\mathrm{m}} \\
\text { (a.u.) }\end{array}$ \\
\hline \multicolumn{6}{|c|}{ Chaetoceros brevis } \\
\hline 15 & $0.26 \pm 0.05$ & 0.18 & $0.51 \pm 0.01$ & $4.92 \times 10^{-15}$ & $0.16 \pm 0.10$ \\
\hline 18 & $0.37 \pm 0.06$ & 0.26 & $0.55 \pm 0.08$ & $6.13 \times 10^{-15}$ & $0.10 \pm 0.06$ \\
\hline 38 & $0.45 \pm 0.06$ & 0.35 & $0.54 \pm 0.11$ & $8.15 \times 10^{-15}$ & $0.08 \pm 0.04$ \\
\hline 45 & n.d. & 0.45 & $0.51 \pm 0.09$ & $1.21 \times 10^{-14}$ & $0.14 \pm 0.08$ \\
\hline 65 & $0.52 \pm 0.02$ & 0.73 & $0.52 \pm 0.09$ & $2.38 \times 10^{-14}$ & $0.19 \pm 0.13$ \\
\hline 78 & $0.47 \pm 0.05$ & 1.07 & $0.57 \pm 0.04$ & $4.86 \times 10^{-14}$ & $0.31 \pm 0.10$ \\
\hline \multirow[t]{10}{*}{100} & $0.45 \pm 0.05$ & 1.48 & $0.58 \pm 0.04$ & $8.58 \times 10^{-14}$ & $0.30 \pm 0.05$ \\
\hline & & 3.26 & $0.58 \pm 0.06$ & $1.04 \times 10^{-13}$ & $0.34 \pm 0.07$ \\
\hline & & 4.15 & $0.57 \pm 0.11$ & $1.25 \times 10^{-13}$ & $0.36 \pm 0.08$ \\
\hline & & 9.14 & $0.57 \pm 0.08$ & $1.32 \times 10^{-13}$ & $0.32 \pm 0.02$ \\
\hline & & & & $1.83 \times 10^{-13}$ & $0.39 \pm 0.06$ \\
\hline & & & & $3.01 \times 10^{-13}$ & $0.41 \pm 0.11$ \\
\hline & & & & $5.32 \times 10^{-13}$ & $0.35 \pm 0.10$ \\
\hline & & & & $1.18 \times 10^{-12}$ & $0.43 \pm 0.16$ \\
\hline & & & & $8.00 \times 10^{-10}$ & $0.53 \pm 0.09$ \\
\hline & & & & $1.80 \times 10^{-9}$ & $0.54 \pm 0.10$ \\
\hline \multicolumn{6}{|c|}{ Thalassiosira antarctica } \\
\hline 12 & $0.35 \pm 0.06$ & 0.17 & $0.33 \pm 0.08$ & $4.92 \times 10^{-15}$ & $0.19 \pm 0.07$ \\
\hline 15 & $0.51 \pm 0.03$ & 0.27 & $0.54 \pm 0.08$ & $6.13 \times 10^{-15}$ & $0.12 \pm 0.05$ \\
\hline 30 & $0.55 \pm 0.03$ & 0.32 & $0.57 \pm 0.10$ & $8.15 \times 10^{-15}$ & $0.13 \pm 0.06$ \\
\hline 40 & $0.56 \pm 0.02$ & 0.41 & $0.57 \pm 0.11$ & $1.21 \times 10^{-14}$ & $0.17 \pm 0.08$ \\
\hline 50 & n.d. & 0.70 & $0.54 \pm 0.06$ & $2.38 \times 10^{-14}$ & $0.28 \pm 0.10$ \\
\hline 70 & $0.58 \pm 0.02$ & 1.06 & $0.62 \pm 0.02$ & $4.86 \times 10^{-14}$ & $0.24 \pm 0.06$ \\
\hline \multirow[t]{10}{*}{103} & $0.54 \pm 0.01$ & 1.17 & $0.62 \pm 0.01$ & $8.58 \times 10^{-14}$ & $0.23 \pm 0.10$ \\
\hline & & 2.20 & $0.63 \pm 0.02$ & $1.04 \times 10^{-13}$ & $0.38 \pm 0.08$ \\
\hline & & 3.98 & $0.61 \pm 0.03$ & $1.25 \times 10^{-13}$ & $0.36 \pm 0.10$ \\
\hline & & 10.82 & $0.62 \pm 0.03$ & $1.32 \times 10^{-13}$ & $0.38 \pm 0.05$ \\
\hline & & & & $1.83 \times 10^{-13}$ & $0.43 \pm 0.08$ \\
\hline & & & & $3.01 \times 10^{-13}$ & $0.44 \pm 0.08$ \\
\hline & & & & $5.32 \times 10^{-13}$ & $0.50 \pm 0.13$ \\
\hline & & & & $1.18 \times 10^{-12}$ & $0.52 \pm 0.11$ \\
\hline & & & & $8.00 \times 10^{-10}$ & $0.58 \pm 0.03$ \\
\hline & & & & $1.80 \times 10^{-9}$ & $0.57 \pm 0.04$ \\
\hline \multicolumn{6}{|c|}{ Chaetoceros calcitrans } \\
\hline 15 & $0.33 \pm 0.08$ & 0.18 & n.d. & & \\
\hline 17 & $0.38 \pm 0.06$ & 0.41 & n.d. & & \\
\hline 18 & $0.43 \pm 0.07$ & 0.61 & n.d. & & \\
\hline 23 & $0.48 \pm 0.06$ & 0.65 & n.d. & & \\
\hline 58 & $0.49 \pm 0.06$ & 0.85 & $0.40 \pm 0.08$ & & \\
\hline \multirow[t]{4}{*}{95} & $0.57 \pm 0.02$ & 0.95 & $0.40 \pm 0.08$ & & \\
\hline & & 2.93 & $0.41 \pm 0.04$ & & \\
\hline & & 4.20 & $0.52 \pm 0.07$ & & \\
\hline & & 7.70 & $0.52 \pm 0.09$ & & \\
\hline
\end{tabular}

added to final concentrations in a range of from 0.18 to about $10.0 \mu \mathrm{M}$ (Table 1).

Iron experiments. Only Chaetoceros brevis and Thalassiosira antarctica were tested in these experiments. As the diatoms could not be grown into iron limitation in this medium, due to high background concentrations of dissolved Fe (0.3 nM dissolved iron), desferrioxamine B (DFB), a natural siderophore was added to the medium in increasing concentrations of up to $120 \mathrm{nM}$. Tests to exclude toxicity of high concentrations of DFB on the diatoms were routinely performed in all experiments by adding a surplus of iron, after which growth resumed rates representative of non(-iron)-limiting conditions (data not shown). Knowing the background Fe concentration, the concentration $(0.5 \mathrm{nM})$ and the conditional stability constant of natural iron ligands ( $K_{\mathrm{Fe} 3+}^{\prime}$ : 22.1; L. J. A. Gerringa, Royal NIOZ, pers. comm.) in the medium, and the concentration and the conditional stability constant of DFB ( $K_{\mathrm{Fe} 3+}^{\prime}$ : 21.6; Witter et al. 2000), the concentration of $\mathrm{Fe}^{\prime}$ (all inorganic $\mathrm{Fe}$ species; C. brevis and C. calcitrans, Table 1) was calculated (for details see Timmermans et al. 2001b).

Analyses. The cultures were checked daily using flow cytometry (Beckman Coulter Epics XL-MCL). The excitation wavelength was $488 \mathrm{~nm}$, with the trigger on chlorophyll autofluorescence of the cells. At least 1000 cells were counted in each culture. In between the dilution of the cultures to keep them exponentially growing, we determined the net growth rates $(\mu$, based on total cell numbers), photosynthetic efficiencies $\left(F_{\mathrm{v}} / F_{\mathrm{m}}\right)$ and cell death rates $(\delta$, see below) over 3 to 5 consecutive days. The results were averaged and plotted against irradiance, silicate $\left(\mathrm{Si}(\mathrm{OH})_{4}\right)$ and inorganic iron (Fe') concentrations. In order to exclude potential effects of the light regime, samples were always taken at the same time in the light:dark cycle. Growth rates were fitted using a non-linear Monod fit (Monod 1950), rendering maximum growth rates $\left(\mu_{\max }\right)$ and the halfsaturation value $\left(K_{\mathrm{m}}\right)$ with respect to irradiance, $\mathrm{Si}(\mathrm{OH})_{4}$, or $\mathrm{Fe}^{\prime}$ concentration.

A PAM fluorometer (Pulse Amplitude Modulated-CONTROL Universal Control Unit, WATER-mode, Walz) was used to determine $F_{0}$ (autofluorescence), $F_{\mathrm{m}}$ (maximum fluorescence) and $F_{\mathrm{v}} / F_{\mathrm{m}}$ (photosynthetic efficiency, where $F_{\mathrm{v}}=F_{\mathrm{m}}-F_{0}$ ) of the diatom samples in relation to the different experimental conditions.

The presence and number of dead diatom cells were determined using the fluorochrome SYTOX Green (Invitrogen), a cyanine stain with high affinity for nucleic acids. SYTOX Green can only penetrate cells with permeabilised plasma membranes, here defined as dead cells (Veldhuis et al. 2001). Prior to the cell death assays, tests were carried out on live and preserved (dead) cells to determine the optimal time of incubation and optimal concentration of SYTOX 
Green. Preservation was done overnight at room temperature, using different fixatives: either formaldehyde (1\% final concentration, Chaetoceros brevis, Thalassiosira antarctica) or glutaraldehyde (0.5\% final concentration, Chaetoceros calcitrans). For all 3 species an incubation with $0.5 \mu \mathrm{M}$ final concentration SYTOX Green (freshly diluted from a $50 \mu \mathrm{M}$ working stock in Milli-Q water stored at $-20^{\circ} \mathrm{C}$ ) for $10 \mathrm{~min}$ in the dark, at room temperature was chosen (Figs. 1 \& 2). Samples were analysed using flow cytometry, with the trigger on chlorophyll autofluorescence. Cells were only considered dead if the DNA/green fluorescence signal exceeded the auto-green fluorescence by at least 5-fold (emission wavelength at $525 \pm 20 \mathrm{~nm}$ ). Live cells showed only a minimum 3 -fold increase of autofluorescence. Although some species-specific differences in staining results were observed in the refinement of the SYTOX staining system, most notably in C. brevis (Fig. 2, staining as a function of the SYTOX concentration), the SYTOX concentration and staining time as specified above were considered to be optimal. Cell death rates were calculated according to Eq. (1), suitable for the batch phase of the cultures (Brussaard et al. 1997), such that:

$$
\delta=\frac{\ln x_{t}-\ln x_{0}}{t \cdot\left\{\left[\frac{(x+y)_{t}-(x+y)_{0}}{y_{t}-y_{0}}\right]-1\right\}}
$$

where $\delta$ is the specific cell death rate $\left(\mathrm{d}^{-1}\right), x$ is the number of living cells and $y$ is the number of SYTOX Green stained (i.e. dead) cells at time $t$ and time 0 , respectively. It was assumed that only SYTOX Greenstained cells were dead. No signs of viral infection were found in the cultures of the 3 diatom species used (C. P. D. Brussaard unpubl. data).

\section{RESULTS}

\section{Cell death rates in relation to irradiances}

The calculated cell death rates of Chaetoceros brevis, Thalassiosira antarctica and Chaetoceros calcitrans (Fig. 3) ranged from 0 to $0.26 \mathrm{~d}^{-1}$ and were only related to the irradiance levels for T. antarctica (Fig. 3b). For this species we found, at the lowest irradiances ( $<15 \mu \mathrm{mol}$ photons $\mathrm{m}^{-2} \mathrm{~s}^{-1}$ ), strongly enhanced cell death rates of about $30 \%$ of the $\mu_{\max }$ growth rate. In $C$. brevis and C. calcitrans, cell death rates were low $\left(<0.05 \mathrm{~d}^{-1}\right.$; Fig. 3a,c) and increased only slightly between 20 and $40 \mu \mathrm{mol}$ photons $\mathrm{m}^{-2} \mathrm{~s}^{-1}$. The growth rates of all 3 species tested decreased with decreasing irradiances (Fig. 3). For C. brevis and T. antarctica, growth halted at the lowest tested irradiance level of $15 \mu \mathrm{mol}$ photons $\mathrm{m}^{-2} \mathrm{~s}^{-1}$ (Fig. 3a,b). C. calcitrans
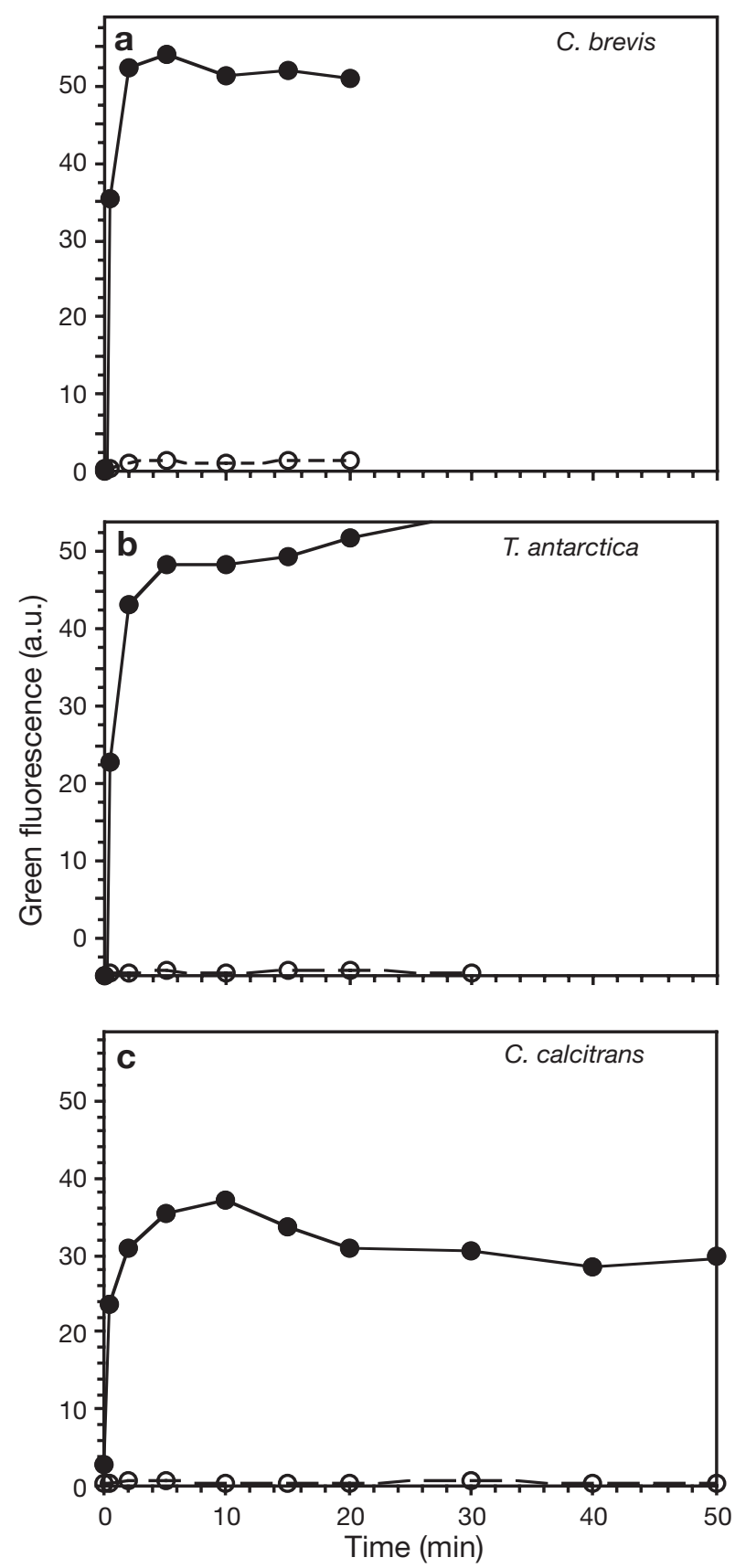

Fig. 1. Green fluorescence intensity (a.u.: arbitrary units) in cultures of (a) Chaetoceros brevis, (b) Thalassiosira antarctica and (c) Chaetoceros calcitrans after staining with SYTOX Green as a function of time $\left(\mathrm{min}^{-1}\right)$. $\bullet$ : fixed (dead) cells (formaldehyde or glutaraldehyde, depending on the diatom species, see 'Materials and methods'); O: live cells. An incubation time of $10 \mathrm{~min}$ was taken as standard to be used for the experiments

maintained growth even at the lowest irradiance level (Fig. 3c). Calculated $\mu_{\max }$ were similar for the 3 species tested $\left(0.72\right.$ to $\left.0.75 \mathrm{~d}^{-1}\right)$, matching the published growth rates for species of the Thalassiosira and Chaetoceros genera under light-replete conditions 


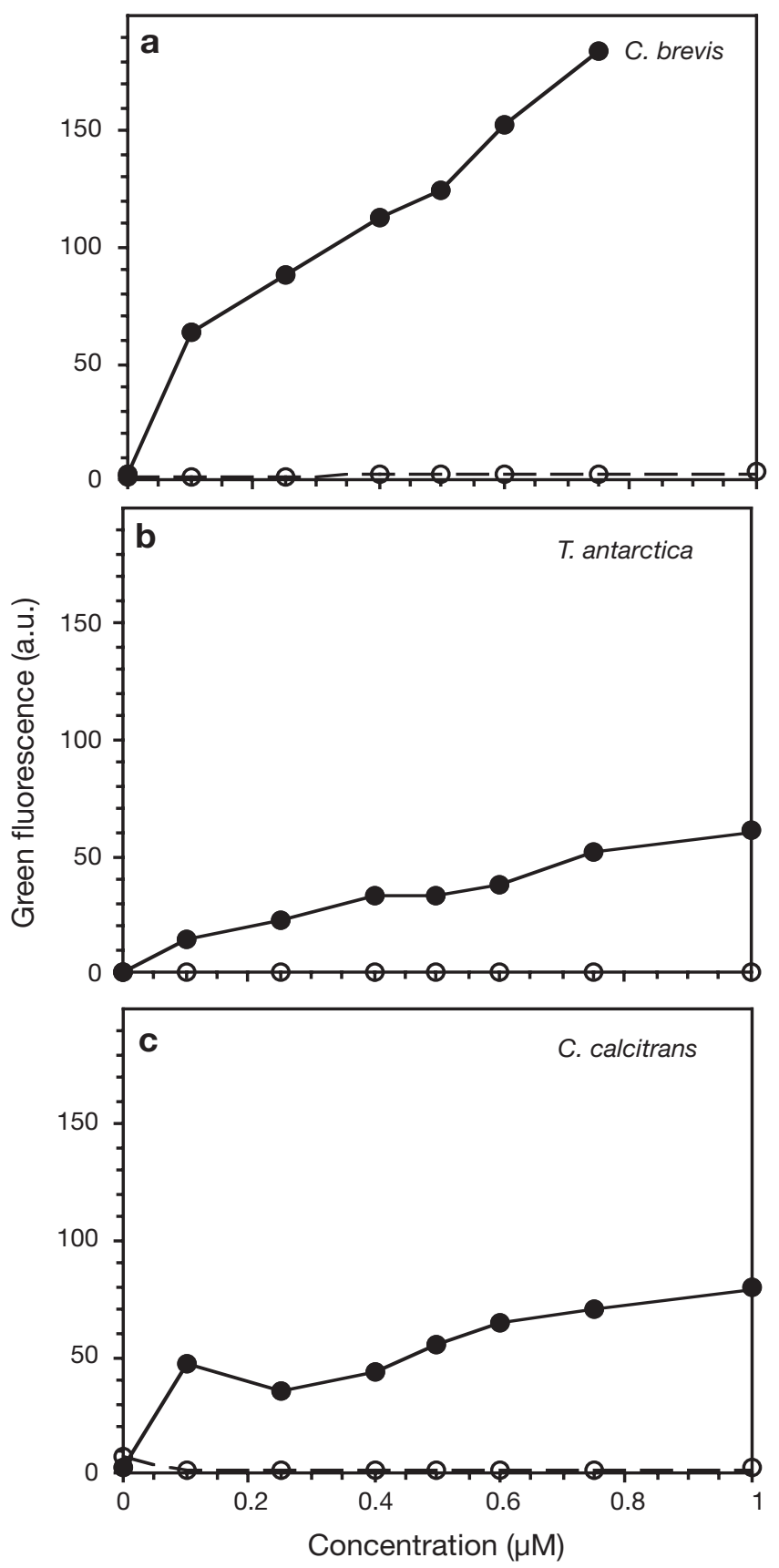

Fig. 2. Green fluorescence intensity (a.u.: arbitrary units) in cultures of (a) Chaetoceros brevis, (b) Thalassiosira antarctica and (c) Chaetoceros calcitrans as a function of SYTOX Green final concentration. fixed (dead) cells (formaldehyde or glutaraldehyde, depending on the diatom species, see 'Materials and methods'); O: live cells. A final concentration of $0.5 \mu \mathrm{M}$ SYTOX Green was used for the experiments

(Timmermans et al. 2001a, Claquin et al. 2002). The decline in growth rates of the 3 diatom species tested with reducing irradiance is comparable to that found for other marine diatoms (Laws \& Banister 1980, Geider et al. 1986). Calculated $K_{\mathrm{m}}$ values with respect
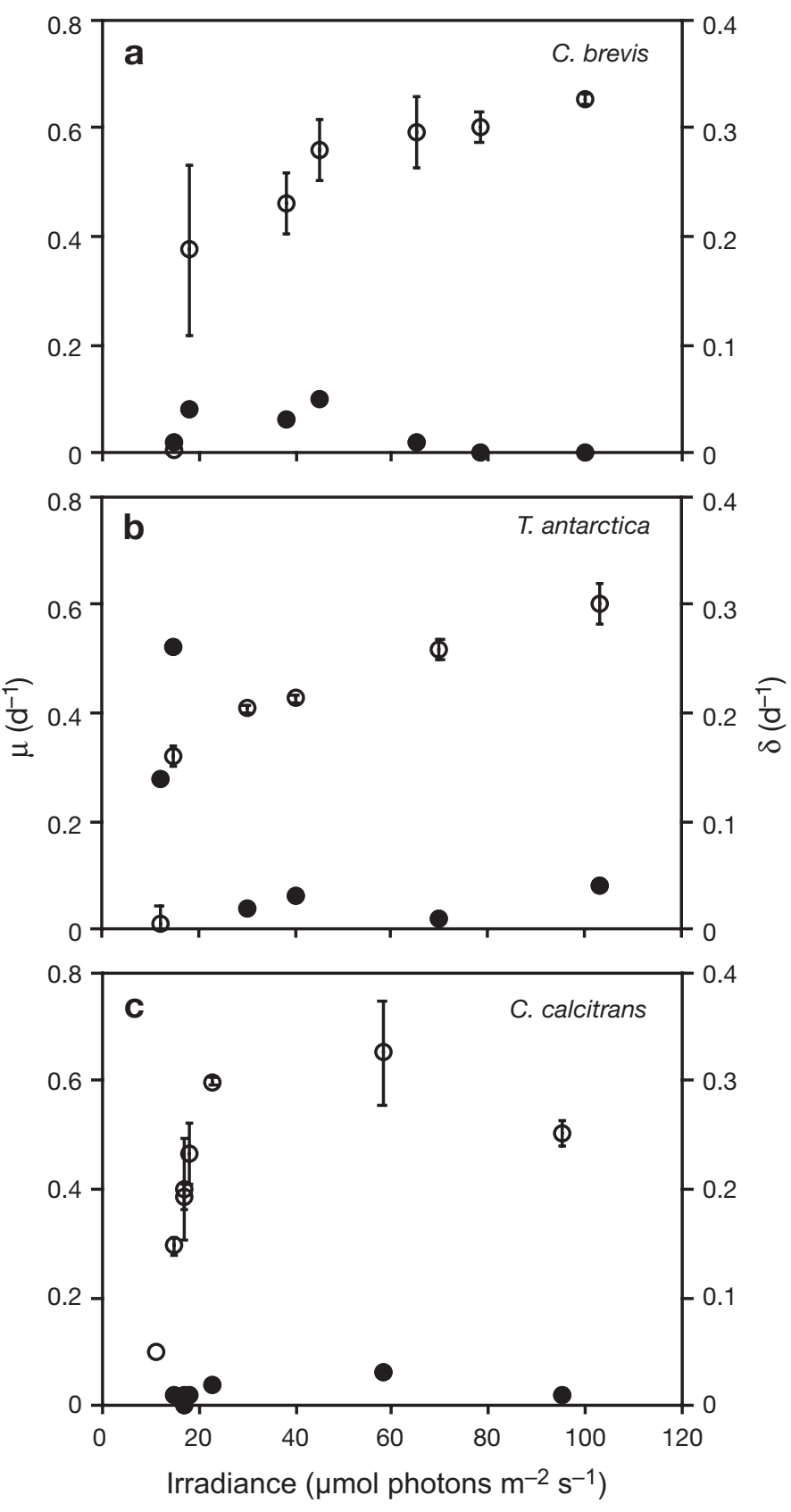

Fig. 3. Cell death rates $(\delta, \bullet)$ and growth rates $(\mu, 0)$ versus irradiance in cultures of (a) Chaetoceros brevis, (b) Thalassiosira antarctica and (c) Chaetoceros calcitrans. $\delta$ were calculated according to Eq. (1); $\mu$ were calculated based on changes in cell abundances over time. Note the difference in scale for $\delta$ compared to Figs. $4 \& 5$. For $\mu$, data points indicate average $( \pm S D, n=3)$. When no error bars are visible, they are smaller than the symbol

to irradiance levels varied between 12 (C. calcitrans), 20 (C. brevis) and 22 (T. antarctica) $\mu \mathrm{mol}$ photons $\mathrm{m}^{-2}$ $\mathrm{s}^{-1}$. In all 3 species tested, $F_{\mathrm{v}} / F_{\mathrm{m}}$ values increased from 0.3 to $0.5-0.6$ with increasing irradiance levels (Table 1). 


\section{Cell death rates in relation to silicate concentrations}

For Thalassiosira antarctica a clear relation between $\delta$ and silicate concentrations was observed (Fig. 4b), increasing from 0.01 to $0.08 \mathrm{~d}^{-1}$ with de-
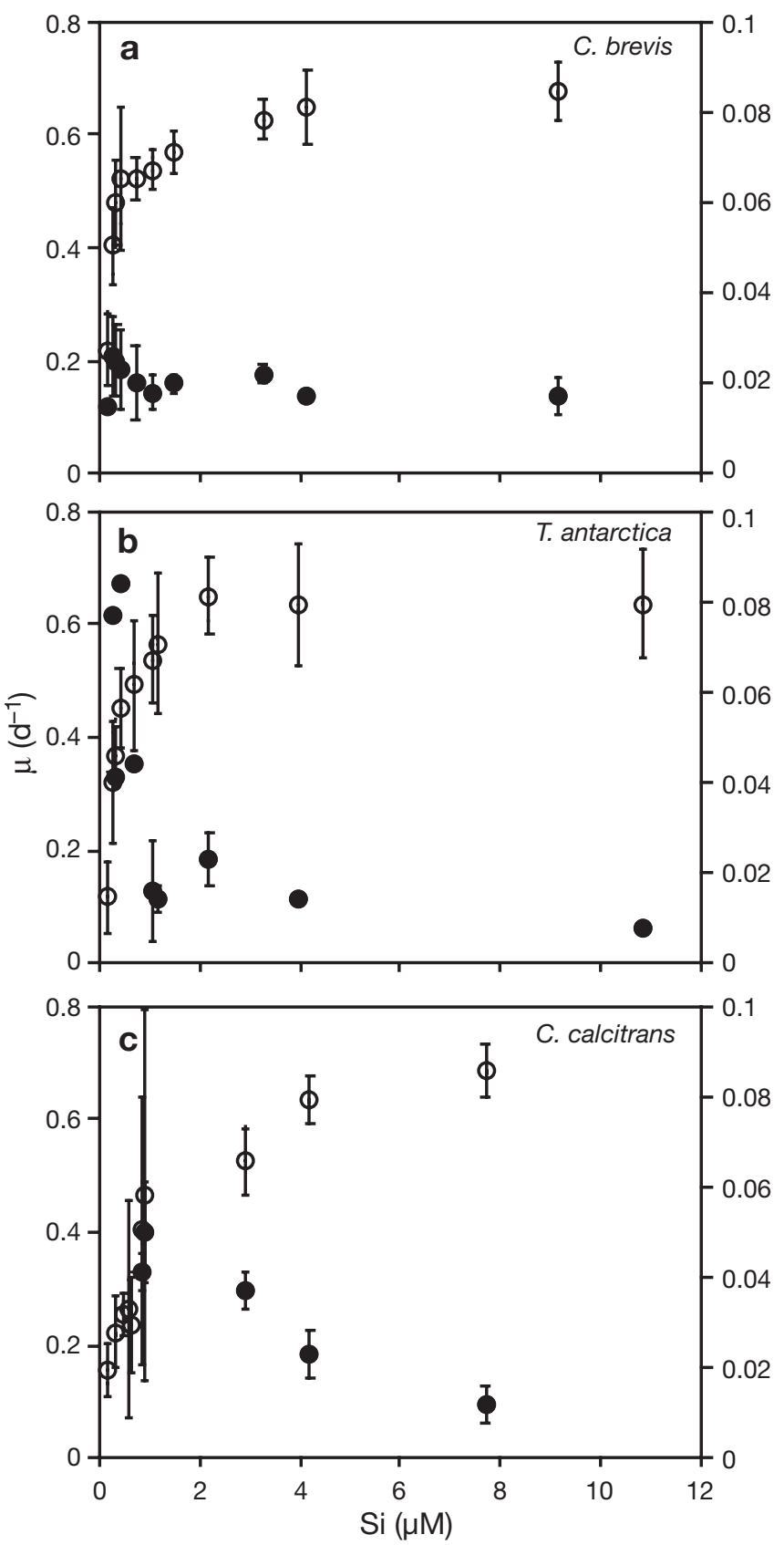

Fig. 4. Cell death rates $(\delta, \bullet)$ and growth rates $(\mu, 0)$ versus silicate concentrations in cultures of (a) Chaetoceros brevis, (b) Thalassiosira antarctica and (c) Chaetoceros calcitrans. Calculations of $\delta$ and $\mu$ as indicated for Fig. 3. Note the difference in scale for $\delta$ compared to Figs. $3 \& 5$. For $\mu$, data points indicate average $( \pm S D, n=3)$. When no error bars are visible, they are smaller than the symbol creasing silicate concentrations. In cultures of Chaetoceros calcitrans, a similar but weaker response was observed ( $<0.02$ to $0.04 \mathrm{~d}^{-1}$; Fig. $\left.4 \mathrm{c}\right)$. Chaetoceros brevis showed minimal variation in $\delta$ in response to varying silicate concentrations (Fig. 4a). Growth rates of the 3 diatom species decreased with decreasing silicate concentrations (Fig. 4), in agreement with previous studies on marine diatoms (see review by MartinJézéquel et al. 2000). In cultures of $C$. brevis and $T$. antarctica a sudden drop in growth rates was observed (silicate concentrations $<1 \mu \mathrm{M}$ ), whereas $C$. calcitrans showed a more gradual decline in growth rate, starting also at higher silicate concentrations $(<4 \mu \mathrm{M})$. Even at the lowest silicate concentrations tested $(0.18 \mu \mathrm{M})$, growth of the 3 species never halted. Calculated $\mu_{\max }$ were comparable to those reported for the species in the irradiance experiments: $0.65 \mathrm{~d}^{-1}$ for $T$. antarctica, $0.69 \mathrm{~d}^{-1}$ for $C$. brevis and $0.76 \mathrm{~d}^{-1}$ for $C$. calcitrans. Calculated $K_{\mathrm{m}}$ values with respect to silicate were $0.16 \mu \mathrm{M}$ for $T$. antarctica, $0.25 \mu \mathrm{M}$ for $C$. brevis and $0.85 \mu \mathrm{M}$ for $C$. calcitrans. For $C$. brevis and C. calcitrans, $F_{\mathrm{v}} / F_{\mathrm{m}}$ values were always high and indicated good photosynthetic efficiency, with values $>0.5$ for all $\mathrm{Si}$ concentrations tested (Table 1$) . F_{\mathrm{v}} / F_{\mathrm{m}}$ for $T$. antarctica was $>0.54$, except for the lowest silicate concentration of $0.17 \mu \mathrm{M}$ $(0.33$; Table 1$)$. For $C$. calcitrans, $F_{\mathrm{v}} / F_{\mathrm{m}}$ decreased slightly from 0.52 to 0.40 with decreasing silicate concentrations (Table 1).

\section{Cell death rates in relation to iron concentrations}

Cell death rates of Chaetoceros brevis and Thalassiosira antarctica were virtually zero $\left(<0.01 \mathrm{~d}^{-1}\right)$ in the iron limitation experiments and appeared non-related to the iron concentration (Fig. 5). Both diatom species showed reduced growth rates $\left(<0.2 \mathrm{~d}^{-1}\right)$ only at extremely low iron concentrations (below $10^{-13} \mathrm{M}$ $\left.\mathrm{Fe}^{\prime}\right)$, but growth in both species never halted. The apparent $\mu_{\max }$ were similar for $T$. antarctica and $C$. brevis $\left(0.40 \mathrm{~d}^{-1}\right)$, which was about $40 \%$ lower than the $\mu_{\max }$ in the light and silicate experiments. The calculated $\mu_{\max }$ in all 3 experiments (light, silicate, iron limitation) should, in principle, be the same under replete conditions. This was the case for the light- and silicate-controlled conditions. The medium for the Fecontrolled cultures differed from the light- and silicate-controlled one, as a different type of natural seawater was used as the basis (see 'Materials and methods'). The lower apparent $\mu_{\max }$ in the Fe-limitation experiments indicated that the culture conditions were not replete in the most optimal case. However, this does not alter our general findings on the effects of Fe limitation on cell death. The $K_{\mathrm{m}}$ values with 


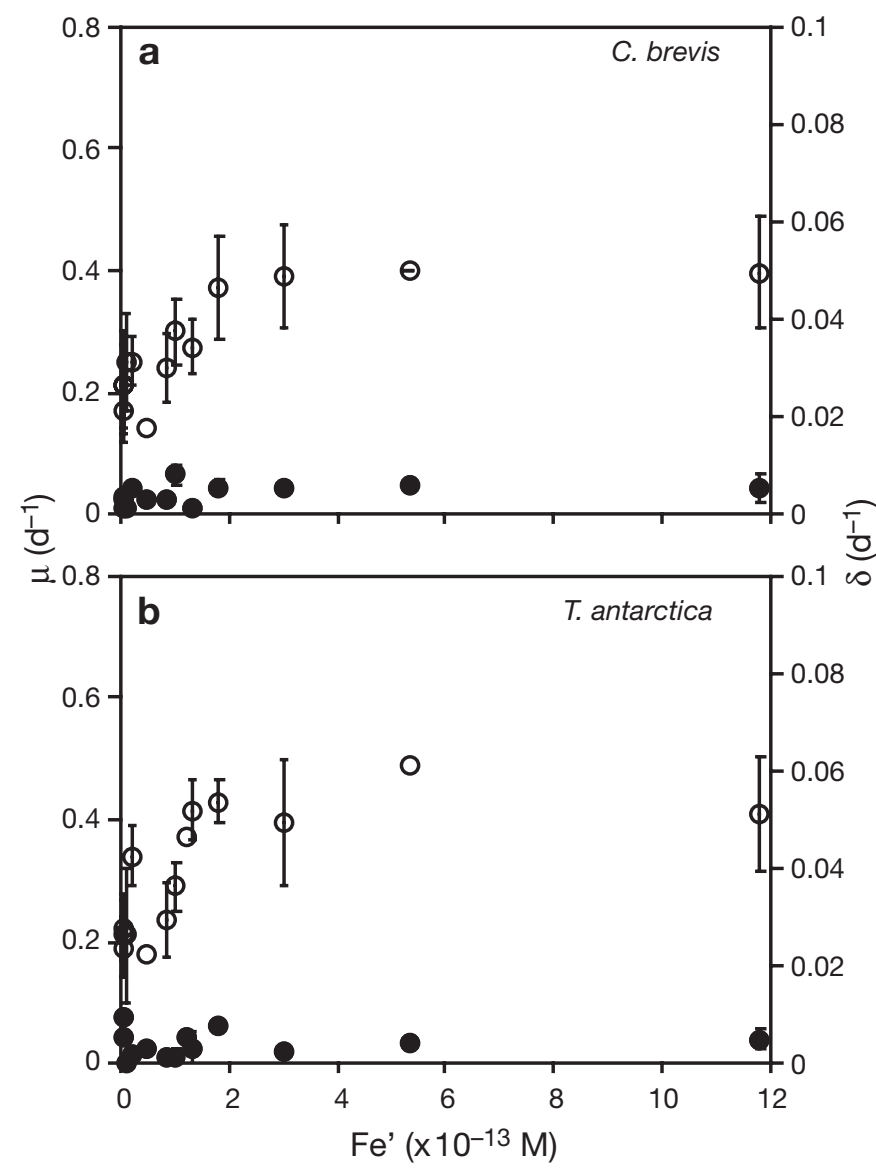

Fig. 5. Cell death rates $(\delta, \bullet)$ and growth rates $(\mu, 0)$ versus

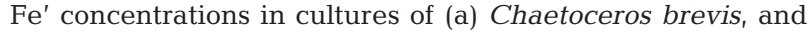
(b) Thalassiosira antarctica. Calculations of $\delta$ and $\mu$ as indicated for Fig. 3. Note the difference in scale for $\delta$ compared to Figs. $3 \& 4$. For $\mu$, data points indicate average $( \pm \mathrm{SD}, \mathrm{n}=3)$. When no error bars are visible, they are smaller than the symbol. The $\mathrm{Fe}^{\prime}$ concentrations were calculated as explained in the 'Materials and methods'

respect to $\mathrm{Fe}^{\prime}$ varied between $1.0 \times 10^{-14} \mathrm{M}$ for $T$. antarctica and $2.1 \times 10^{-14} \mathrm{M}$ for $C$. brevis. These $K_{\mathrm{m}}\left(\mathrm{Fe}^{\prime}\right)$ values were much lower than those reported for 4 large Antarctic diatom species (Timmermans et al. 2004) or the average $K_{\mathrm{m}}\left(\mathrm{Fe}^{\prime}\right)$ values for 12 diatoms as reported by Sarthou et al. (2005), indicating a $K_{\mathrm{m}}\left(\mathrm{Fe}^{\prime}\right)$ range from $0.59 \times 10^{-12}$ to $1.12 \times 10^{-9} \mathrm{M}$. Besides temperature (Eppley 1972) and the size of the cells (Sunda \& Huntsman 1995, Timmermans et al. $2001 \mathrm{~b})$ as $K_{\mathrm{m}}$-regulating factors, the conditional stability constants for artificial or natural organic complexes used to calculate $\mathrm{Fe}^{\prime}$ concentrations may also cause considerable variance in $K_{\mathrm{m}}$ values (Witter et al. 2000, Timmermans et al. 2001b). The index for photosynthetic efficiency $\left(F_{\mathrm{v}} / F_{\mathrm{m}}\right)$ decreased strongly with decreasing iron concentrations from 0.6 to 0.1 at $\mathrm{Fe}^{\prime}$ concentrations from $8 \times 10^{-10}$ to $2 \times 10^{-14} \mathrm{M}$ (Table 1, C. brevis and T. antarctica).

\section{DISCUSSION}

In this study we present cell death rates $(\delta)$ based on single cell analyses for marine diatoms under various growth-limiting conditions, combined with results on growth rates and photosynthetic efficiencies. Clear species-specific differences were recorded. The highest death rates were observed for Thalassiosira antarctica, with a maximum $\delta$ of $0.26 \mathrm{~d}^{-1}$ under light limitation. Our results imply that light, and to some extent also silicate, is a principal factor controlling diatom biomass, species succession and distribution. Despite generally low cell death rates, irrespective of the controlling factor, it was mainly the growth rate that declined with increasing limitation. It should be noted that in this study the cells were acclimated to the specific limiting conditions. Under certain (meso)eutrophic conditions, nutrient depletion may be a fast process and therefore the effect on cell death rates may be more pronounced.

\section{Irradiance experiments}

It is clear that low light levels result in enhanced cell death in phytoplankton. In our study only Thalassiosira antarctica experienced enhanced cell death (to $0.26 \mathrm{~d}^{-1}$ ) at low irradiance. Related to this, growth rate and photosynthetic efficiency were also reduced at the lower irradiance levels. Both signals are indicative of serious physiological stress (Geider \& LaRoche 1994). These findings indicate that $T$. antarctica can endure prolonged stress of low irradiance (30 to $40 \mu \mathrm{mol}$ photons $\mathrm{m}^{-2} \mathrm{~s}^{-1}$ ) well. The Chaetoceros species tested in this study, $C$. brevis as model species for cold water and C. calcitrans as a typical species of temperate waters, did not show enhanced cell death rates despite the fact that both $\mu$ and $F_{\mathrm{v}} / F_{\mathrm{m}}$ did decrease. Previously, light stress as a factor inducing cell death in diatoms has only been investigated by Berges \& Falkowski (1998), Peters \& Thomas (1996) and Peters (1996), but these studies were under relatively extreme culture conditions, since the algae were kept in the dark for a long period. A field study measuring total cell lysis in the Mediterranean reported different death rates for the cyanobacteria Synechococcus and Prochlorococcus related to the light regime (Agustí 2004). It was suggested that the difference in cell death rates between these 2 species was an underlying process structuring the phytoplankton community. Our results suggest that the 2 Chaetoceros species may survive periods of reduced light better than the Thalassiosira species. This observation seems to contradict the general idea that polar phytoplankton species may have evolved special adaptations for survival under the variable and low light intensities that are commonly experienced by 
these species (Peters 1996, Peters \& Thomas 1996). Our study shows, however, that species-specific differences in response to low light periods do occur in diatoms, and that one should therefore not generalise too much. For a more conclusive statement, more polar versus temperate species should be studied.

\section{Silicate experiments}

To our knowledge, our study provides the first data on Si-controlled cell death rates for marine diatoms. As for light stress, Thalassiosira antarctica was most sensitive, as shown by the enhanced cell death rates at low silicate concentrations $\left(0.26 \mathrm{~d}^{-1}\right.$ at $\left.0.2 \mu \mathrm{M}\right)$. The 2 Chaetoceros species showed only very low cell death rates $\left(<0.04 \mathrm{~d}^{-1}\right) . \mu_{\max }$ were generally lower than those of other diatoms studied thusfar (Martin-Jézéquel et al. 2000), possibly related to the relatively low temperatures at which the diatoms were grown in the present study (Eppley 1972). In our experiments, remarkably low $K_{\mathrm{m}}(\mathrm{Si})$ values $(0.16$ to $0.85 \mu \mathrm{M})$ were calculated, most likely the consequence of working with acclimated, small diatom cells, known to have lower $K_{\mathrm{m}}$ values (Eppley et al. 1969). Generally, higher $K_{\mathrm{m}}(\mathrm{Si})$ are reported for marine diatoms. For example, Sarthou et al. (2005) reported a range in $K_{\mathrm{m}}(\mathrm{Si})$ values of 0.2 to $22 \mu \mathrm{M}$ (average $3.9 \pm 5.0 \mu \mathrm{M}$ ). For natural diatom communities in the Monterey upwelling system a $K_{\mathrm{m}}$ for silicate uptake of $4.2 \mu \mathrm{M}$ (White \& Dugdale 1997) and limitation of biogenic silicate production at $5 \mu \mathrm{M}$ (Brzezinski et al. 1997) were reported. The photosynthetic efficiency showed only a minimal response to changes in silicate concentrations. The most likely explanation for this is that the silicate metabolism is regarded as an energy-cheap process (Raven 1983), without direct involvement of photosynthetic energy (Martin-Jézéquel et al. 2000).

In temperate regions, high-nutrient conditions are commonly found in spring and early summer (Ragueneau et al. 2000). Under these conditions, blooms of diatoms like Chaetoceros calcitrans can develop rapidly. After the depletion of silicate to concentrations well below $1 \mu \mathrm{M}$, other phytoplankton species take over. Based on our results and assuming that we can extrapolate the work we did with acclimated cells to the natural system, population declines of temperate diatoms like $C$. calcitrans will be caused by reduced growth rates rather than by increased cell death rates. Alternatively, in the Southern Ocean, the habitat of Chaetoceros brevis and Thalassiosira antarctica, silicate concentrations in the surface waters are commonly well above $10 \mu \mathrm{M}$ (Levitus et al. 1993) and usually remain high. This silicate concentration is sufficient to maintain high growth rates, accompanied by low cell death rates.

\section{Iron experiments}

Obviously, low iron concentrations lead to physiological stress in the diatom cells, as exemplified in the reduced growth rates $\left(0.2 \mathrm{~d}^{-1}\right.$, a $50 \%$ reduction of the apparent $\left.\mu_{\max }\right)$, as well as in a low photosynthetic efficiency $\left(F_{\mathrm{v}} / F_{\mathrm{m}}<0.2\right)$, confirming previous work in which suboptimal values of $F_{\mathrm{v}} / F_{\mathrm{m}}$ were regarded as strong evidence for physiological stress (Geider \& LaRoche 1994, Behrenfeld \& Kolber 1999). Remarkably, these photosynthetically unhealthy diatoms did not show increased cell death rates. On the contrary, cell death rates were extremely low $\left(<0.01 \mathrm{~d}^{-1}\right)$ and appeared to be independent of the $\mathrm{Fe}^{\prime}$ concentrations. The ability to maintain growth even under low Fe' concentrations confirms the low iron requirements of small diatoms, either by a favourable surface to volume ratio, and/or by efficient use of the available iron (Sunda \& Huntsman 1995, Timmermans et al. 2001b). These results provide experimental evidence for the so-called ecumenical iron hypothesis (Cullen 1995): small cells would not be growth limited by low Fe concentrations, but rather controlled in numerical abundance by other loss factors like grazing. The low cell death rates as observed in this study indicate that natural mortality is not an important loss factor, at least for fully acclimated diatoms. An earlier study using Chaetoceros brevis as the model species did, however, show enhanced cell death rates upon lifting the iron (and light) limitation (Timmermans et al. 2001a). This may indicate that cell death rates can vary under different experimental (and natural) conditions. Obviously, more research is needed on the effects of co-limitation (iron and light), as well as on the effects of the sudden removal of a limitation on cell death rates of phytoplankton.

Acknowledgements. The authors acknowledge E. van Tellingen, L. van Opstal and V. Sperber for their practical support. Further, we thank A.-C. Baudoux, A. Noordeloos and B. van der Wagt for their willingness to help out. This manuscript benefitted from comments made by the reviewers.

\section{LITERATURE CITED}

Agustí S (2004) Viability and niche separation of Prochlorococcus and Synechococcus cells across the Central Atlantic Ocean. Aquat Microb Ecol 36:53-59

Agustí S, Duarte CM (2000) Strong seasonality in phytoplankton cell lysis in the NW Mediterranean littoral. Limnol Oceanogr 45:940-947

Agustí S, Sánchez MC (2002) Cell viability in natural phytoplankton communities quantified by a membrane permeability probe. Limnol Oceanogr 47:818-828

Behrenfeld MJ, Kolber ZS (1999) Widespread iron limitation of phytoplankton in the South Pacific Ocean. Science 283:840-843

Berges JA, Falkowski PG (1998) Physiological stress and cell death in marine phytoplankton: induction of proteases in 
response to nitrogen or light limitation. Limnol Oceanogr 43:129-135

Bidle KD, Falkowski PG (2004) Cell death in planktonic, photosynthetic microorganisms. Nat Rev Microbiol 2:643-655

Boyd PW, Crossley AC, DiTullio GR, Griffiths FB, Hutchins DA, Queguiner B, Sedwick PN, Trull TW (2002) Control of phytoplankton growth by iron supply and irradiance in the subantarctic Southern Ocean: experimental results from the SAZ Project. J Geophys Res 106:31573-31583

Brussaard CPD (2004) Viral control of phytoplankton populations - a review. J Eur Microbiol 51:125-138

Brussaard CPD, Riegman R, Noordeloos AAM, Cadee GC and 5 others (1995) Effects of grazing, sedimentation and phytoplankton cell-lysis on the structure of a coastal pelagic food-web. Mar Ecol Prog Ser 123:259-271

Brussaard CPD, Kempers RS, Kop AJ, Riegman R, Heldal M (1996) Virus-like particles in a summer bloom of Emiliania huxleyi in the North Sea. Aquat Microb Ecol 10:105-113

Brussaard CPD, Noordeloos AAM, Riegman R (1997) Autolysis kinetics of the marine diatom Ditylum brightwellii (Bacillariophyceae) under nitrogen and phosphorus limitation and starvation. J Phycol 33:980-987

Brzezinski MA, Phillips DR, Chavez FP, Friederich GE, Dugdale RC (1997) Silica production in the Monterey, California, upwelling system. Limnol Oceanogr 42:1694-1705

Claquin P, Martin-Jézéquel V, Kromkamp J, Veldhuis MJW, Kraay GW (2002) Uncoupling of silicon compared with carbon and nitrogen metabolisms and the role of the cell cycle in continuous cultures of Thalassiosira pseudonana (Bacillariophyceae) under light, nitrogen, and phosphorus control. J Phycol 38:922-930

Cullen JJ (1995) Status of the iron hypothesis after the openocean enrichment experiment. Limnol Oceanogr 40: 1336-1343

Eppley RW (1972) Temperature and phytoplankton growth in the sea. Fish Bull (Wash DC) 70:1063-1085

Eppley RW, Rogers JN, McCarthy JJ (1969) Half-saturation constants for uptake of nitrate and ammonium by marine phytoplankton. Limnol Oceanogr 14:912-920

Franklin DJ, Berges JA (2004) Mortality in cultures of the dinoflagellate Amphidinium carterae during culture senescence and darkness. Proc R Soc Lond B 271: 2099-2107

Franklin DJ, Brussaard CPD, Berges JA (2006) What is the role and nature of programmed cell death in phytoplankton ecology? Eur J Phycol 41:1-14

Geider RJ, LaRoche J (1994) The role of iron in phytoplankton photosynthesis, and the potential for iron-limitation of primary productivity in the sea. Photosynth Res 39:275-301

Geider RJ, Osborne BA, Raven JA (1986) Growth, photosynthesis and maintenance metabolic costs in the diatom Phaeodactilum tricornutum at very low light levels. J Phycol 22:39-48

Kirchman DL (1999) Phytoplankton death in the sea. Nature 398:293-294

Laws EA, Banister TT (1980) Nutrient- and light-limited growth of Thalassiosira fluviatilis in continuous culture, with implications for phytoplankton growth in the ocean. Limnol Oceanogr 25:457-473

Lee DY, Rhee GY (1997) Kinetics of cell death in the cyanobacterium Anabaena flos-aquae and the production of dissolved organic carbon. J Phycol 33:991-998

Lee DY, Rhee GY (1999) Kinetics of growth and death in

Editorial responsibility: William Li,

Dartmouth, Nova Scotia, Canada
Anabaena flos-aquae (Cyanobacteria) under light limitation and supersaturation. J Phycol 35:700-709

Levitus S, Conkright ME, Reid JL, Najjar RG, Mantyla A (1993) Distribution of nitrate, phosphate and silicate in the world's oceans. Prog Oceanogr 31:245-273

MacIntyre HL, Kana TM, Anning T, Geider RJ (2002) Photoacclimation of photosynthesis irradiance response curves and photosynthetic pigments in microalgae and cyanobacteria. J Phycol 38:17-38

Martin-Jézéquel V, Hildebrand M, Brzezinski MA (2000) Silicon metabolism in diatoms: implications for growth. J Phycol 36:821-840

Monod J (1950) La technique de la culture continue. Theorie et applications. Ann Inst Pasteur Lille 79:390-410

Peters E (1996) Prolonged darkness and diatom mortality. 2. Marine temperate species. J Exp Mar Biol Ecol 207:43-58

Peters E, Thomas DN (1996) Prolonged darkness and diatom mortality. 1. Marine Antarctic species. J Exp Mar Biol Ecol 207:25-41

Ragueneau O, Tréguer P, Leynaert A, Anderson RF and 11 others (2000) A review of the Si cycle in the modern ocean: recent progress and missing gaps in the application of biogenic opal as a paleoproductivity proxy. Global Planet Change 26:317-365

Raven JA (1983) The transport and function of silicon in plants. Biol Rev 58:179-207

Sarthou G, Timmermans KR, Blain S, Tréguer P (2005) Growth physiology and fate of diatoms in the oceans: a review. J Sea Res 53:25-42

Sunda WG, Huntsman SA (1995) Iron uptake and growth limitation in oceanic and coastal phytoplankton. Mar Chem 50:189-206

Timmermans KR, Davey MS, van der Wagt B, Snoek J, Geider RJ, Veldhuis MJW, Gerringa LJA, DeBaar HJW (2001a) Co-limitation by iron and light of Chaetoceros brevis, $C$. dichaeta and C. calcitrans (Bacillariophyceae). Mar Ecol Prog Ser 217:287-297

Timmermans KR, Gerringa LJA, DeBaar HJW, van der Wagt B, Veldhuis MJW, DeJong JTM, Croot PL, Boye M (2001b) Growth rates of large and small Southern Ocean diatoms in relation to availability of iron in natural seawater. Limnol Oceanogr 46:260-266

Timmermans KR, van der Wagt B, DeBaar HJW (2004) Growth rates, half saturation constants, and silicate, nitrate, and phosphate depletion in relation to iron availability of four large open ocean diatoms from the Southern Ocean. Limnol Oceanogr 49:2141-2151

Van Boekel WHM, Hansen FC, Riegman R, Bak RPM (1992) Lysis-induced decline of a Phaeocystis spring bloom and coupling with the microbial foodweb. Mar Ecol Prog Ser 81:269-276

Veldhuis MJW, Kraay GW, Timmermans KR (2001) Cell death in phytoplankton: correlation between changes in membrane permeability, photosynthetic activity, pigmentation and growth. Eur J Phycol 36:167-177

Walsh JJ (1983) Death in the sea - enigmatic phytoplankton losses. Prog Oceanogr 12:1-86

White KK, Dugdale RC (1997) Silicate and nitrate uptake in the Monterey Bay upwelling system. Cont Shelf Res 17:455-472

Witter AM, Hutchins DA, Butler A, Luther GW (2000) Determination of conditional stability constants and kinetic constants for strong model Fe-binding ligands in seawater. Mar Chem 69:1-17

Submitted: May 5, 2006; Accepted: November 22, 2006 Proofs received from author(s): January 26, 2007 